HStud 24 (2010)2, 273-291 DOI: 10.1556/HStud.24.2010.2.8

\title{
KING MATTHIAS IN HUNGARIAN AND EUROPEAN FOLKLORE
}

\author{
VILMOS VOIGT
}

\author{
Eötvös Loránd University, Budapest \\ Hungary
}

\begin{abstract}
The folklore surrounding the figure of King Matthias offers an illuminating example of the international nature of both the culture of the Renaissance and folklore itself. The following paper offers an overview of the history of much of the research and scholarship concerning the figure of the king in European folklore (particularly the folklore traditions of Central Europe), followed by a discussion of the historical layers of inter-ethnic (international) Matthias folklore.
\end{abstract}

Keywords: King Matthias, Corvin, Hunyadi, renaissance, myth, legend, folklore, Hungary, Central Europe

Kralj Matjaž King Matthias of the Slovenes, successor to Kresnik, and legendary conqueror of the Turks. Like Kresnik, Matjaž too was married to his sister, Alenčica, whom, in legend, he rescued from the Turks, or in Slovenian traditional ballad, from the underworld. Matjaž is also a king in the mountain, sleeping till the day of Slovenia's utter need, when he will emerge and save everything...

It is said that during World War II the peasants thought King Matjaž would ride again and save Slovenia (Funk \& Wagnalls, 1950, v. 1, 589-90).

The above citation is the only entry in which reference is made to King Matthias in the 1950 Funk \& Wagnalls Standard Dictionary of Folklore Mythology and Legend, which to this day remains the most famous such reference work. Yet in Hungary and the bordering countries it is a well-known fact that the deeds of King Mátyás (Matthias) Corvin (original family name: Hunyadi) are of interest to this day not only to historians and cultural historians, but also to folklorists. This is due quite simply to the fact that tales, legends, myths, proverbs, etc. in which the king figured have been recorded not only in Hungarian folklore, but also in the Slovenian, Slovak, and Ruthenian folklore of the past several centuries (practically speaking up to the present day). Many prominent Hungarian and non-Hungarian researchers of folklore have examined these themes. While the 
folklore phenomena of the Carpathian Basin or the northern and western areas of the Balkans are interrelated in thousands of other respects, the figure of the Hungarian king, who perished more than a half a millennium ago, is possibly the most recognized common subject in this region, which itself can only be truly assessed within the framework of international research.

The fact that for a long time innumerable stories have surrounded the Romanian origins of the father of King Matthias, János Hunyadi, the famous military leader who defeated the Ottoman armies at the battle of Várna in 1444, and the possible lineage of the Hungarian king Sigismund of Luxembourg, who was also Holy Roman Emperor, is part of this international perspective. Numerous Hungarian heroes (among them the young János Hunyadi, as Jankula, Matthias' uncle Mihály Szilágyi, and even King Matthias and his captains) regularly figure in Southern Slav heroic epic poetry. And even these broader relationships cannot be comprehended entirely if we fail to take into consideration further and more remote historical and folklore data and interpretations of these data, including material also from Albanian, Moravian, Czech, Austrian and Italian sources.

The imagology of King Matthias is a highly illuminating topic in European comparative folklore, a topic to which we can recently add further parallels, even those of a typological (i.e., not-genetical) nature. Here we can list only some motifs, e.g. the boy born amidst miraculous premonitions, the Christian ruler battling with the pagans, the king who protected the people and was the scourge of the lords, the ruthless yet just ruler, the sovereign who is not only not of aristocratic lineage, but is of outright peasant origin, and who explores the country in disguise, and finally the figure of the immortal returning hero all constitute models that could have been concocted in the folklore of many peoples.

The arrival and a certain blossoming of humanism and the Renaissance in 15th century Hungary, the influx of Italians and from other nations, the splendor until then unheard of in Hungary, the spread of court culture, the carefully tailored political and military propaganda, the breaking of the ideological monopoly of the Church, and eventually the final disbanding of the much feared professional soldiery (the king's so-called Black Army) into a gang of robbers represented new phenomena that could easily be transformed into motifs in local or comparative folklore.

Neither was the private life of King Matthias short of novelistic twists and turns. The execution of László (his elder brother), the captivity in Prague, the betrothal of the daughter of the Czech ruler Jiřy (George) Poděbrad, the election of the very young Matthias as king of Hungary by the common people on the "frozen waters of the Danube," the decision of the king to turn soon on his earliest supporters, the averting of several conspiracies (in which the majority of his favored Hungarian humanists in fact took active part), his ceaseless and endless military campaigns, his second marriage to a princess of Naples, his long and multifarious 
relationship with the historical Dracula (Vlad Tepes), the capture of Vienna, his ambitions to become King of Bohemia, prince of Silesia, and indeed prince-elector of the Holy Roman Empire, and ultimately his unexpected and peculiar death and the fate of the illegitimate son, János Corvin chosen as his successor - all seemed almost to be recorded not simply as history but as fiction. And indeed his contemporaries themselves must have often conversed and debated or invented explanations concerning such events. Seeing as how within the span of only a few decades after his death the greatest peasant war in Hungary took place (1514), the Hungarian kingdom itself ceased to exist following the defeat at Mohács in 1526, the southern and central regions of the country were conquered in the coming 150 years by the Ottoman Empire, and then the century of Reformation and religious struggles began - the period of Matthias Heyday's rule can seem soon by the coming generations something of an irretrievable "golden age," and to some in Hungary does seem so even to this day.

Folklorists have known for some time that an idealized image of the king emerged invariably in the folklore of the above mentioned peoples. Ever since these texts were recorded in the folklore of these nations (essentially since the 19th century) the question has arisen: where lie the origins of this international agglomeration of multi-genre texts mentioning King Matthias? In the case of Hungarians (Croatians and Slovaks) one could suppose that by this time (in the 19th century) the already long and official historical consciousness in Hungary had become part of the broader consciousness of the people (however, presumably through intermediaries), though in the case of Slovenian and Ruthenian, Romanian (etc.) folklore such an explanation is by no means self-evident.

As early as 1842 or 1843 Matija Majar Ziljski published (in German) Slovenian songs about King Matthias. The first comparative scholar of folklore concerning king Matthias was the Galician philologist Zenon Kuzelja, a student of Vatroslav Jagić, the famous Slavist in Vienna. In a monograph (Kuzelja, 1906) he summarized these traditions of Slavic peoples (and Hungarians). Kuzelja is a representative of the comparative study of Slavonic languages and literatures of his time, most notably accepting the views on the migration of themes and motifs held by the eminent Russian philologist, A. N. Veselovsky. While we may be familiar today with a far broader array of information and texts, the methods and conclusions of Kuzelja (and of his teachers) are nevertheless still deserving our attention. A monograph published half a century later by Slovak folklore scholar Ján Komorovský (1957) essentially adopts this approach, at most adding more historical and cautionary Marxist social commentary. In Slovenian philology several generations of outstanding scholars examined this subject. Ivan Grafenauer first surveyed the legends (1951a) and later the songs (1951b). He also gave scholarly consideration to the hypothesis that in Slovenian folklore Matthias could be considered a substitute for an almost mythical figure of earlier texts. The possibil- 
ity of an "ancient, mythical" interpretation arose in particular in the case of Slovenian narrative or epical-lyrical songs, an interpretation that was also maintained by scholars of novels and novelists to the extent that they substituted Matthias not for the figure of the Hungarian king, but for outlaw barons and rebels from among the people. Fortunately distinguished Slovenian scholars such as Milko Matičetov, Vilko Novak, Vlado Nartnik and others took a fairly cautious stance on this question. They and their colleagues drew attention to the fact that the themes of the texts mentioning Matthias also contain well known international motifs (which can nearly all be analyzed individually and which point into various and divergent directions). Of these the most notable is the Orpheus-motif known from the antiquity, and later the so-called Kyffhäuser motif of the hero waiting in a cave and returning with his army (see Lukács, 2001). Igor Kercha (2001) links the duration of the Ruthenian Matthias tradition to the present day with the historical consciousness of the local population of the most north-east part of the historical Hungary, which has existed for as long as folk texts have been collected in this Subcarpathian region.

As far as Hungarian researchers of folklore are concerned, although from the end of the 18th century to the conclusion of the 19th the theoreticians of this field (Mátyás Rát, Miklós Révai, István Kultsár, Ferenc Kölcsey, János Erdélyi, or even János Kriza, Arnold Ipolyi, Pál Gyulai, etc.) considered contemporary Hungarian folklore as the depository of the historical past, it was precisely the figure of King Matthias that they did not place in the foreground. While they published narratives containing the figure of Matthias, they neglected to emphasize their "historical" importance. The Hungarian national poet Sándor Petőfi reveals why he advises that no (modern) heroic epic should be written about Matthias: "Just don't take a king as your hero, not even Matthias. He too was a king, and one is a dog and the other is another dog" (as bad as the other). (See his letter to the famous Hungarian fellow poet, János Arany, February 23, 1847.) After the hesitant initiative of Lajos Abafi, in fact Elek Benedek was the first (in 1902, in other words fairly late) to place Matthias in the spotlight in Hungarian publications for the general public on folk poetry. The anecdotes related to the king were published by Béla Tóth in a six-volume series of common anecdotes in Hungary in a scattered way (Magyar anekdotakincs from 1898 onwards). It constitutes a work of unique importance for Hungarian national and historical identity, but it is not a collection of proper folklore texts. It is also from here that Hungarian belletrists borrowed their stories of Matthias once inspired by folklore. But the writers and the folklorists in Hungary at first they were unaware, however, that the role of Matthias in oral tradition was not unique to Hungarian culture.

Needless to say, this is not applicable anymore to the scholarly study folklore in Hungary. Ágoston Pável was the first (1909) who connected the Slovenian "Or- 
pheus theme" with Hungarian texts. As a matter of fact, up until the end of his life he endeavored to provide a monographic survey of the Slovenian and Hungarian King Matthias lore, which he was not, however, able to complete, the lectures he gave at the beginning of the 1940s at the University in Szeged notwithstanding. István Szémán (1912) reviewed Kuzelja’s book, Rezső Szegedy (1916) examined the role of the Hunyadi family in Southern Slav epic poetry, and in various writings József Ernyey (1921) called for the importance of the Czech Matthias tradition. On numerous occasions various scholars in Hungary expounded on the wealth of Southern Slav folklore. It is therefore all the more surprising that in the most prestigious ethnographic reference work (A Magyarság Néprajza) published during the interwar years professor Sándor Solymossy (1935: 218-27, 253-4), then the leading Hungarian folklorist, basically fails to recognize the majority of outstanding international connections of Hungarian folklore concerning King Matthias. As early as the 1940's, however, his student Gyula Ortutay accentuated precisely this international context in articles and university lectures, urging the completion of a comparative monograph (Ortutay, 1942). His efforts, unfortunately, were effortless and he himself failed to write the so much heralded summarizing essay. János Horváth, the most notable positivist literary historian of the interwar years (who incidentally took an interest in Hungarian folklore, at least that of the 19th century), does not discuss the stories pertaining to King Matthias in his writings. Another literary historian, Béla Zolnai (1921), also concerned himself exclusively with the literary history of the official Matthias tradition.

Fortunately the situation today is quite different. Imre Ferenczi, Zoltán Ujváry, and in recent decades Ildikó Kríza (2007), Zoltán Magyar and others have discussed the Matthias tradition on innumerable occasions as it has figured in historiography and folklore, to mention only the most outstanding, well-known scholars. István Lukács (2001) provided an overview of Slovenian material and András Dávid (1978) and recently Károly Jung (2008) examined Southern Slav folklore connections. Among literary historians Tibor Kardos attempted in a manner sometimes hardly credible but always ingenious to assemble the information from the Matthias era into a unified whole. István Fried reviewed the results of the comparative Hungarian philology. One may hope with good reason that the current anniversary year 2008 of the rule of king Matthias brought further scholarly achievements.

After this introductory survey two questions remain to be dealt with: what are the historical layers of this inter-ethnic Matthias folklore; and how might one characterize this from a social-historical perspective? The difficulty of the task and the limits of the scope provided here notwithstanding I nevertheless attempt to reach some kind of an answer. 


\section{"Matthias Folklore" before King Matthias}

One should note first the possibility of a kind of Matthias folklore before King Matthias. Given that the international parallels of several texts have old records (examples include e.g., the heroic first strata of Solomon and Markolf texts), the possibility arises that the name of the king was inserted in these later. This is conceivable but hard to prove. There are, in any event, no such examples dating back this far in Hungarian, despite the parallels in motifs. About the Orpheus and Kyffhauser motifs' stratification I have already mentioned the common opinion in comparative folklore.

\section{New, Emerging Genre(s) in the Age of King Matthias}

Concerning the new genres that emerged in the age of King Matthias, it was Tibor Kardos (1955) who thought of the trufa (jest, fabliaux, Schwank) genre in Hungarian as of Italian origin and a genre to which there are references dating from the time of King Sigismund of Luxembourg. This is somehow conceivable, although no one has come across such texts from Hungary, but the only information available concerning the trufa even from the era of King Matthias is of a philological plausibility. At this historical point the references to practical joke ap-

pear in Hungary. (Examples include the story of the "traveling showman throwing peas through a keyhole" who is rewarded by King Matthias with a basket of peas so that he can practice, or the story "there was once a dog-market in Buda," which might be rendered in an English tale as, "once it came to pass, but only once.") With respect to the first occurrences of these and their later transformation as part of tradition little more than conjecture has been made. On the other hand, the propaganda value of such stories is clear: the (hidden) message is that the King has a most modern technique in his castle, including doors with key-holes (a novelty in Europe then), or, he has constantly developing markets with surprising new wares to sell and buy.

\section{The Kinds and Genres of Royal Propaganda}

It is commonly known that the Italian Renaissance marked the beginning of a new era in the thousand-year-old ruler's propaganda in Europe. Hungary and especially King Matthias followed the new trend: bringing specialists to his kingdom educated specifically for this task. One of them, Antonio Bonfini, not only created a family genealogy (De Corvinianae domus origine libellus) but also 
wrote the ambitious complete "Hungarian history" (Rerum ungaricarum decades), a work that took into consideration the writings of Hungarian historians. Janus Pannonius, an extremely talented poet from the Hungarian Croatia schooled to be a minion of the king, was charged with, among other tasks, the provision of a heroic epistle collection from the battlefield, or a similarly magnifying poetic description of the king's battles (Annales), instead of which the haughty and individualistic poet wrote reflective elegies about the for him too long time he spent with the royal army fighting the Turks (speaking but most exclusively about his own health, dreams and astrologic speculations). The Latin verses written by Janus Pannonius remained familiar to European humanist poets, but no folklore concerning King Matthias originated with him. Bonfini, on the other hand, remained an inexhaustible source for Hungarian historians for centuries.

One of the most interesting of these Corvinian propagandistic works is the small collection of reports entitled De egregie, sapienter, iocose dictis ac factis regis Matthiae /ad ducem Johannem, eius filium liber/ "the excellent, clever and witty sayings and deeds by King Matthias," dedicated to his son) by Galeotto Marzio (cca. 1427-1497), from which dozens of anecdotes could be borrowed any time. Galeotto became a friend of Janus Pannonius while studying in Verona. It was on Janus' invitation that he made a short visit to Hungary in 1461. The Italian Humanist came for a longer stay in 1465 only to return home in 1472 at the time of the conspiracy against the Corvin king. Because of his heretical work (De incognitis vulgo - 1477) Galeotto was imprisoned in Venice during the Inquisition and was only set free through the intervention of (among others) King Matthias. Following this he came to Hungary on many occasions to meet with Matthias, though he wrote the above mentioned collection of anecdotes not in Hungary but in Italy in 1485, dedicating it to the King's son, János Corvin. It is not likely that Galeotto ever returned to Hungary after this year. We know little of the last years of his life (by 1497 he had died). The typical "itinerant humanist" with a life full of twists and turns was therefore first the hireling of King Matthias, later became a member of the opposition against him, only then to find himself in his debt in the end. In the small collection of stories (De ... dictis ac factis...) depicting life in the Hungarian court (what one might refer to as brief sketches in contemporary journalism) he proved to be a clever PR-specialist and staunch adherent of the modern and cultured king. The Italian author ascribes to the Hungarian King some proverbs (with more or less credibility) that might be a good topic for further research. E.g., in a later written vernacular document the well known quotation from Cicero (Pro Mil. IV.10), "Silent leges inter arma," was referred to as one of the favorite sayings of Matthias in an innovative form: "Inter arma silent Musae," which is, in fact, not registered in international paremiology, but is well known also in modern Hungarian. We do not know how well Galeotto's Latin work was known in Hungary at the time of his contemporaries and afterwards. 
And although a few people looked for signs of what we might call "heretical" ideologies in this work, none were found.

Ultimately, apart from generalities, we have little idea of how the Hungarian king made practical use of the propagandistic works that he himself commissioned.

\section{On the Trail of the "Political Officers" of the Black Army}

In Hungarian language literature we can read, in addition to the texts adapted by official historians, "popular" stories about the era of King Matthias first in the chronicle by István Bencédi Székely entitled Cronica ez világnak jeles dolgairól ('Chronicle about Notable Affairs of this World', 1559) and in the work of Gáspár Heltai entitled Krónika az magyaroknak dolgairól ('Chronicle about the Affairs of the Hungarians'), which was published posthumously by his widow in 1575 . He makes mention of the popular stories as texts that he heard from the "former soldiers of the Black Army."

Székely, born in Bencéd (Bențid in Romanian) in the region of Udvarhelyszék (Transylvania) sometime after 1500, studied first as a Franciscan monk and then as student at the university in Cracow. From 1538 on he was an evangelical (Lutheran) pastor (and later in the church he belonged to a so-called sacramentarian movement). We know of printed works of his dating from this time that were written with the intention of addressing all strata of the population in Hungary. These included calendars, hymnals, catechisms and translations of psalms. He even embarked on a Hungarian translation of the Bible. The Transylvanian Saxon Kaspar Helth (Gáspár Heltai) was a decade younger than Székely. Born around 1510 in Heltau, today Cisnădie (Nagydisznód in Hungarian), he began as a Catholic priest. He learned Hungarian only around 1536 and became a Lutheran (later he too became a sacramentarian and indeed at the end of his life was outright antitrinitarian). He joined hands with another Saxonian in Transylvania, the printer Georg Hoffgreff of Kolozsvár (Klausenburg, today Cluj/Napoca) in 1550. Heltai's remarkably diverse printing activities led to the wide range publication of popular and educational materials in Hungarian. It is not easy to decide whether in the 1530s István the "Székely" and the Saxon from Heltau in fact met with the discharged soldiers of the Black Army who allegedly recounted the Matthias stories. It was with the help of this army that the seventeen-year-old János Corvin attempted (unsuccessfully) to seize power at the time of the death of King Matthias in 1490. In 1492 Pál Kinizsi, once the chief commander of the king's army, a very cruel soldier routed the Black Army. Kinizsi died only a few years later (1494) and János Corvin, who in the meantime had taken the side of the Jagellonian King Wladislaw (Ulászló) II of Hungary, and as the viceroy (banus) of Croatia and Slavonia oversaw the defense of the country's south western territories against the 
Turks, died in 1504 just above his thirtieth birthday. This constituted the point in time up to which the former soldiers of King Matthias' army, or at least small contingents of them, might have stayed together, sharing some "common folklore." By 1530 the former soldiers of the Black Army would have been around 70 years old. It is conceivable that people listened with greater interest to their recountings in Transylvania, which in contrast with the rest of the country the Ottoman armies had largely avoided. We know little more, however, of exactly how and where István Székely or Heltai might have come into contact with this oral tradition. Nevertheless, both of their works are distinguished by knowledge of contemporary public opinion, the knowledge of the simple folk. We have no reason to doubt that the soldiers of the Black Army were "ideologically" instructed by "political officers." No doubt one of the main themes was that the professional and mercenary army, not only well trained and successful but also forceful and ruthless, was waging war in the name of "righteous and noble" goals in lands that lay usually far from Buda. As for the "mother tongue" of most of the soldiers we can admit Hungarian, Czech, German, and further languages, because the soldiers were recruited from several regions. It made the international spread of narratives more easy. Like so many iron fisted kings of feudal times Matthias himself regularly came into conflict with the nobility, and although the life of the simple people was certainly not easy under the rule of the bellicose king, who continuously had to collect more and more taxes in order to finance military ventures, yet under subsequent rulers the burdens simply grew while the benefits dwindled. It is conceivable that from the beginning of the 16th century the popularity of the "our once great king" grew. Matthias obiit, iustitia periit 'King Matthias died, justice perished' - popular opinion might have said.

\section{The Splendid Image of the Corvinus Kingdom in Contemporary Europe}

The tidings of a dynamic reformer and a rich, splendor loving king quickly spread, mainly in Austrian, Czech, Italian, and Romanian territories, but also in more distant lands, among Germans and Poles, in the Balkans and even in the Ottoman Empire. His envoys traveled widely in Europe and foreign delegates, who were masterfully dazzled in his court, came to Hungary from all directions, from Stambul and Rome, from the Holy German Empire and even from Muscovy. The king was indeed a man of erudition, a sovereign ruler who had a firm opinion on many questions. Those delivering to Hungary weapons, luxury items, and splendidly decorated books no doubt spoke in their home countries of the ruler who assured such an immensely rich market. Yet this could not have been the thematic basis of a "European folklore" about Matthias Hunyadi. If we take into consideration that in 1477 the queen Beatrix of Aragon's (from Naples) sister, Eleonora, 
duchess of Ferrara, sent 56 varieties of carnival masks to Hungary and that on other occasions lions (who - according to the narratives - later died just on the day of Matthias' death!) were sent to the king's court this nevertheless does little more than give the impression that this was a wealthy and somehow barbarian country (like today's Kuwait or Abu Dhabi) where there was money to be spent on all sorts of luxury. And the idea that Matthias was the "hero" of Machiavelli's work $\mathrm{Il}$ principe ('The Prince' - 1513) or that he was one of the main protagonists of the work of the German Emperor Maximilian I entitled Weiskunig ('The Wise King' with a pun to 'The White King'), an allegory and illustration of court pomp and splendor, is a mere suggestion put forward only by later scholars. It is nevertheless certain that inscriptions and depictions in many places immortalized the Hungarian king, and not only in Vienna, the place of his death, but even on the wall of a watch-tower in the Silesian (in Lusatia) town of Bautzen. When in 1541 the Turks sacked the royal library in the Buda castle containing the magnificently illuminated Corvina codices it is possible that the soldier carrying the voluminous volumes had no previous knowledge of the great Hungarian king, but he must have observed the existing traces of unusual splendor, and the bulk of the treasures sooner or later reached the Sultan's treasure house in Istanbul. (On the carnevalesque features of the court life in Corvinian - and later - Hungary, see Voigt, 2000.)

There was, therefore, some foundation on which folklore, not solely Hungarian, concerning King Matthias could develop. When we read in the first tale of the second night of Le piacevoli notti, the famed collection of tales of Giovan Francesco Straparola (published in Venice in 1550), that Galeotto (a common family name in Italy, with no affiliation to the humanist of King Matthias' court), the rich king known from the so-called "Breton stories" in European tales, weds "la figliuola di Mattias re di Ongaria, Ersilia per nome chiamata" ("the daughter of the Hungarian king Matthias named Ersilia, in comparison with whom there was in her time no one more beautiful, virtuous or refined in courtly life"), we notice that the notorious wealth of the Hungarian king goes without saying, as does the name of the daughter he never actually had.

Writing in the sixth chapter of his well-known book Popular Culture in Early Modern Europe Peter Burke (published first in 1978), speaking on the prototype of the "ruler", mentions King Matthias, who fought against the Turks and after whose reign "justice ceased to exist." When discussing other stereotypical rulers he mentions the king traveling in disguise (i.e., the Harun al-Rasid topos) and lists Matthias among the examples of the Kyffhäuser motif. He is correct in all this and he draws a broad range of examples. Yet precisely because so many figures mentioned in his chapter, from King Arthur to Saint Olaf, the founder of the feudal Norwegian Kingdom, to the "real czar" figures as pretenders to the Russian throne and the bellicose Swedish King Charles XII in the 18th century, seem to embody 
this "prototype" there is no explanation as to how national or international folklore about a particular ruler - in this case King Matthias - develops practically.

Folklore in itself is international; however, the development of individual works and genres must be carefully and separately examined in each case.

\section{The First Non-Hungarian Folkloric Texts Concerning Matthias}

Czech scholars (such as Čeněk Zíbrt and Otakar Hostinský as early as 1888 and 1892) alluded to the fact that from the mid-16th century there are traces of songs mentioning King Matthias in Czech hymnals (see Kuzelja and Komorovský; examples include Pán Bůh z své milosti nyní lid sobě vybíra... [By the All-Merciful Lord God the people has elected...] from 1564, Bože nebeský, ty větrou spojuješ [O Heavenly God, connected with the faith] from 1612 and again in an evangelical hymnal in 1620). Komorovský assumed that these texts were also sung by Slovaks. In a poem by Aleš Knobloch written in 1561 there are two data about melodies that are of relevance to Matthias folklore (Zpivá se jako starodávná píseń vojenská o Králi Matyášovi, Králi Uherském... [On the melody of very old soldiers' songs about King Matthias, the king of Hungary...]). We cannot determine, however, whether they are Czech or Slovak songs, or Hungarian songs that have been translated into a Slavic language.

Among Slovenian scholars, Simon Rutar mentioned in 1879 the comment by Marcantonio Nicoletti (1536-89), notary of Cividale, that the Slovenes in the seaside region of Tolmin "sang in their mother tongues not just about Christ and the saints, but also about the Hungarian King Matthias and other heroes of that people." (Usano essi cantare in versi ne' varii modi della loro lingua le lodi di Christo e de'Beati, nonche di Mattia re d'Ungheria e di altri celebri personaggi

di quella Nazione). Since then this record, which can be dated to the second half of the 16th century, has been mentioned by all philologists examining the Slovenian Matthias tradition. But we do not know which nation the "altri celebri personaggi" belong to (see Grafenauer and Lukács).

There is little doubt that both the Czech and the Slovene records in one way refer to the Hungarian king, which indeed is how they were interpreted by the late authors themselves. Yet the content and texts of the songs are unknown, as is the manner in which they became part of the Slovene and Czech (and Slovak) tradition. If there are references to heroic deeds and soldiers' songs the simplest approach would be to link these songs to the songs of Matthias' army. This constitutes little more than a readily available hypothesis, however. Nor do we know if these songs were translated from Hungarian or if it was only the subject matter, possibly only the name of King Matthias that was Hungarian. 
As for the first folk narratives from Roumania, referring to King Matthias, a German agricultural engineer Arthur Schott was working in 1836-41 and again in 1844-52 in Oravița (Banat, then in southeastern part of Hungary), collecting Romanian folklore. Together with his brother, Albert they have published the very first collection of Romanian folk tales: Walachische Märchen (Stuttgart and Tübingen, 1845), which does not contain stories about King Matthias. But among the texts from his second collection, published originally in the German journal Hausblätter (vol. 4, 1858, 367-71) there is a legend about "Emperor Matei Corvin", who learned the language of the animals, and being a magician visits Tsarigrad (Constantinople). Schott remarks (300-5) that one could read on the trip "in books". Thus the oldest known Romanian folklore text about King Matthias at least to some extent might stem from written sources. All the later Romanian folk legends were collected in Transylvania (Brill, 2006, 295-8). A noted Transylvanian Hungarian folklorist, József Faragó (1997, more recently 2005, 704-5) mentioned two Romanian folk ballads, with the hero's name Mateaşiu Craiu or Mateiaş Crai (King Matthias).

The famous Romanian folklorist, Atanasie Marian Marienescu published the first ballad in a journal Albina (1866, No. 20.), then in his collection of Romanian ballads entitled Poezia poporală. Balade (Popular Poetry. Ballads, vol. II, Vienna, 1867, 92-4). According to the story King Matthias punishes his treacherous lords by destroying the castle of Buda, along with all inhabitants, with gunfire. The story is unknown elsewhere in Romanian or Hungarian balladry. Most probably it stems from the Romanian Banat, where Marienescu from 1862 was working as lawyer. In his rich collection of Romanian folk literature he wanted to find motifs which might be related to historical persons as Marius, Sulla, Hadrian or Aurelian from the Ancient Rome.

The certain teacher Iona Papa collected the second ballad in November 1898, in the region Bravo in Transylvania. It is a common European ballad (international type number Child 75) well known both in Hungarian and Romanian variants. Papa's version is the only one where the hero is named King Matthias. In both cases we find very late and corruptible texts, which do not represent any historical traces of King Matthias in Romanian folklore in the proper sense of the term.

For centuries Hungarian heroes were included as characters in the heroic epic poetry of the Southern Slav peoples (Serbian, Bosnian, Croatian). As the examples of such texts that have come down to us are from later times the task of unraveling their historical layers is not simple. I do not enter here into the very complicated problem of the historical stratification of South Slavic epic poetry. For summaries see Burckhart (1968, 60-3) and Krstić (1984, 524-5). For a folkloristic treatment of several motifs in "non-historical" Serbo-Croatian "epic songs" see 
Milošević-Djordjević (1971, especially 220-1). We find some songs, which mention kralj Matijaš already in the Erlangen manuscript of South Slav heroic songs. This is a collection of 220 song texts, the majority from possibly oral sources. The manuscript can be dated to 1717 and 1730, and some of the texts belong to earlier times of the Serbian-Ottoman wars. Their attitude is clearly against the Turks, and represents Serbian attitudes, but not a Hungarian point of view. Serbian philology and folklore uses the material as for establishing the historical development of Southern Slav epic poetry. Folk or popular variants occur in 19th century collections. We can, however, claim with some certainty that the later collected songs also had precedents. They are essentially of a Southern Slav point of view, so while we may be able to explain the heroes or events on the basis of events and characters of Hungarian history (as e.g., Janko vojvoda, Jankula vojvoda, Sibinjanin Janko = János Hunyadi, Mihailo Svilojevič = Mihály Szilágyi, varadinski ban Petar Dojčin = most probably Péter Dóczi, etc.) we should not, however, assume that they represent Serbian (etc.) adaptations of completed Hungarian texts. (See the works e.g., Dávid, 1978, and especially Jung, 2008 - with detailed textual history of some variants.) The recent publication summarizing Hungarian narratives on King Matthias from the Vojvodina (Raffai, 2008), mostly with recently collected and hitherto unpublished texts, does not show direct Serbian-Hungarian textual interferences.

Conversely we must call attention to the fact that until now scholarship has devoted little attention to the images of Hungarian rulers in the Balkans and
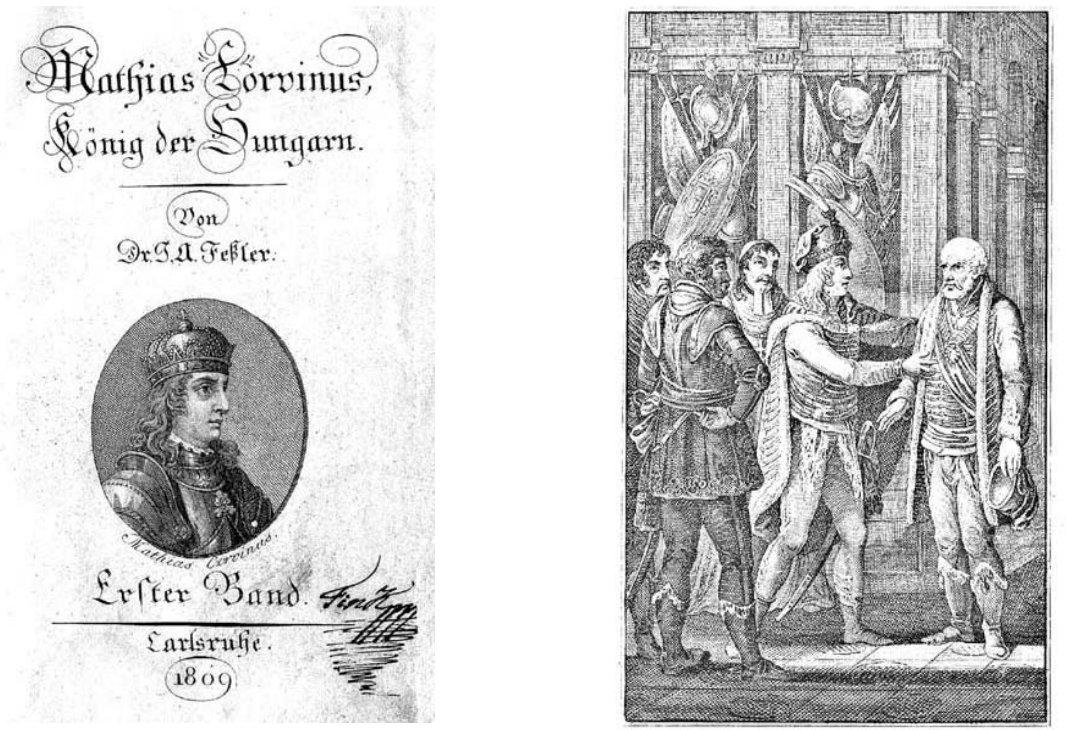

Mathias Corvinus, König der Hungarn, erster Band, von Dr. I. A. Feßler, Carlsruhe, 1809 (without the publisher's name), front pages 
Romania during the time of King Matthias. In this case it would be informative to specify both the similarities and the differences. As for the literary traditions praising or mentioning King Matthias, a thorough and detailed study is yet to be done.

If we turn the pages of any later publications, we find interesting details, little in the way of explanation. For instance, in the third volume of Fessler's Gemälde aus den alten Zeiten der Ungarn (Karlsruhe, 1809) on the frontispice of Matthias Corvinus, König der Ungarn we find an idealized portrait of the king (with an appropriate inscription). But, on the opposite page there is a drawing of a historical scene that scholars have been unable to identify. Five men meet and greet one another at an unidentified event. The third from the left looks like a Lutheran bishop with the Ten Commandments. The central figure looks like the young Matthias, on the opposite page, but without Hungarian royal insignia. If this is intended to indicate that Matthias has not yet been crowned king, the fifth figure, an elderly man, might be either the Czech George Poděbrad, a becoming father-in-law, or Mihály Szilágyi, governor of Hungary. Since the costumes are "historic" but not specific, they are open also to varying explanations.

In order to illustrate by example how complicated these traditions might be, I mention here only one further case. It is a well known fact that in 1487-88, i.e., when his patron king was alive, an Italian humanist in the court of the Hungarian king, Alessandro Tommaso Cortese, wrote a Carmen panegyricum in Latin hexameters honoring him. A later edition of the poem (Hagenau, 1531) was included by the famous Hungarian scholar Johannes Sambucus (János Zsámboky) as an appendix into his then new edition (1606) of the Italian court historian of Matthias, Antonio Bonfini's summary of the Hungarian history: Rerum Hungaricarum Decades. Cortese's epic poem could serve thus as one of the sources of the "Meditations about King Matthias" (as well as to the baroque heroic poem Obsidio Sigetiana) by the famous Hungarian poet and statesman, Nicolaus Zrini (Miklós Zrínyi). When, even considerably later, in Kassa (Kaschau, Košice) a sample of Bonfini's and Istvánffy's Hungarian history was published (Livii Hungarici ... Antonii Bonfini ... Nicolai Istvanfi ...) at the end of the book (on pages 132-66) we can read Cortese's literary work De Matthiae Corvini invictissimi Ungariae Regis laudibus bellicis, a poem among the historical sources, and 250 years after its first publication (see Szörényi, 1993, 26-31).

In summary, when examining the Hungarian Matthias folklore it would be worthwhile to demonstrate old and international connections. This would serve not only to promote the comparative study of folklore but also to further the interpretation of Hungarian historical records.

There are two major problems involved. First, it is not easy to separate the "international" versus "historic" context data. Second, it is not easy to prove the historical "continuity" of texts, narratives, motifs, etc. In many cases the folklore 


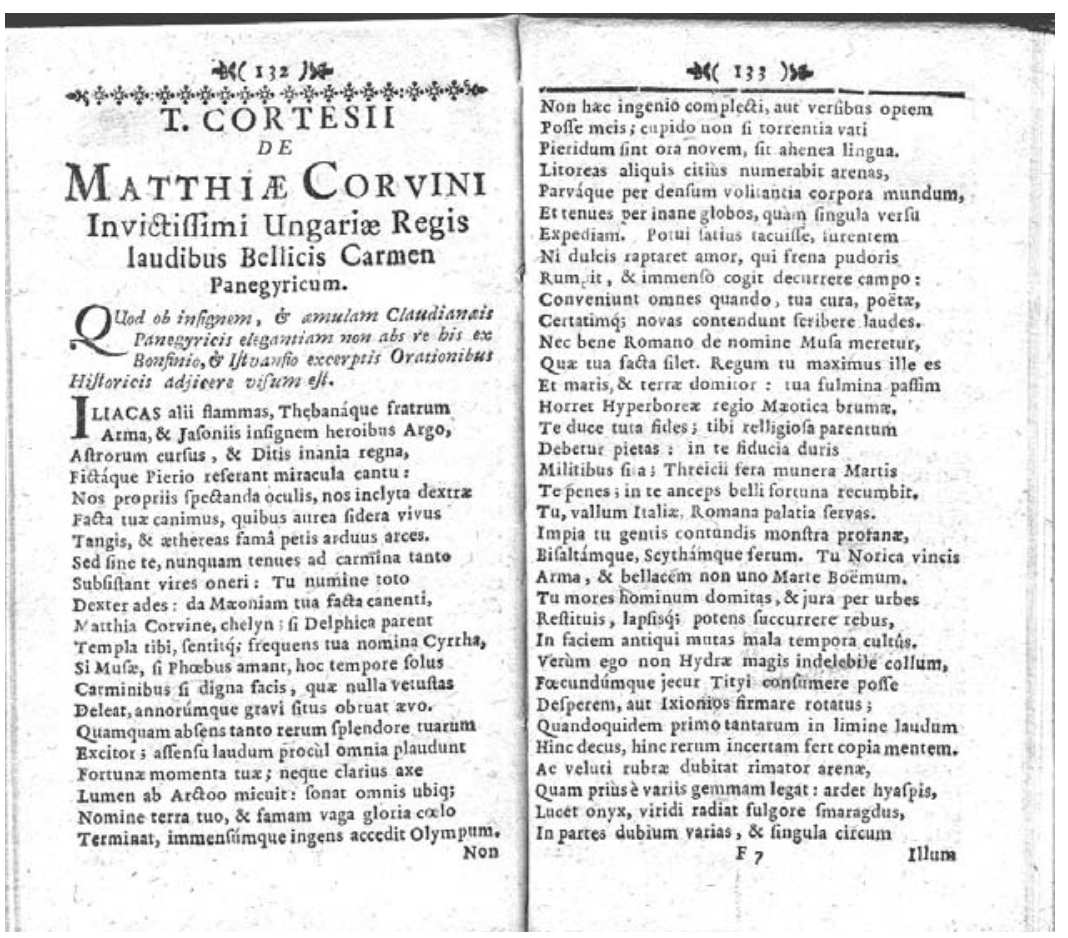

The first pages (132-3) of Cortesius: De Matthiae Corvini ... in Livii Hungarici ...

Antonii Bonfini ... Cassoviae, Typis Academ ... per Joan Henrie. Frauenheim, 1732

publications from the 19th century can only be dated back to popularizing historical works, literary works, schoolbooks, calendars from some earlier time. There are "optimistic" and "pessimistic" scholars in constructing the "continuation" of the "King Matthias lore." I definitely belong to the second group.

It is not difficult to demonstrate that there remain many tasks to be completed, even if we deal with seemingly "long traditions" of that lore.

One of the most well-known elements in the iconography of the Hunyadis is the raven (corvus in Latin, from which the word Corvinus was forcefully derived), carrying a (golden) ring in his beak. We do not know for sure, what was the actual origin of the adopted family name Corvin/us. (Perhaps it was originated from the name of the town Kovin at the borderline of South Hungary, which in fact was owned by the Hunyadi family. But there is no direct evidence supporting the suggestion.) Though several scholars have studied this heraldic motif, we nonetheless have no precise knowledge of its origins. The old references do not describe the story relating to it precisely, alluding instead at most to some kind of ostensibly commonly known explanation.

A strong indication of continuity would be the proverbial lore, i.e., proverbs and sayings mentioning King Matthias. In fact there are such texts, but most of 
them are modern and represent school lore. There are only some possible exceptions. The recent Hungarian collections of proverbs all mention the well-known maxim: meghalt Mátyás király, oda az igazság ('King Matthias has died, gone is justice', but they all draw on Antal Szirmay's book Hungaria in parabolis (1805), i.e., a common source written centuries later. The history of the saying, which can be found not only in Hungary and in languages other than Hungarian, is an interesting, complicated and international topic, which needs further investigation.

The other, today less well-known phrase, "Király Mátyás és Mátyás király," which means simply "Matthias the King and King Matthias," in other words there is considerable difference between two names that apparently seem almost identical, figures on the very personal collection of proverbs by András Dugonics (written from 1792 on, and published in 1820) entitled Magyar példabeszédek és jeles mondások (Hungarian parables and notable sayings, vol. I, 44). Dugonics tells an explanatory story, most probably of his own creation. A shoemaker by the name of Király Mátyás ('King Matthias') lived in the capital Buda, and on the name day of the Corvin King he went to the royal castle to greet the ruler. The guards stopped him, and the shoemaker told them he had the same name as the king and he had come to greet his namesake. The guard replied that the difference between King Matthias and Matthias the King is as great as the difference between a king and a shoemaker. We know from historical documents concerning the development of family names in Hungary that in the time of King Matthias nobody could use the word "King" as family name and Matthias as a given name, especially someone from the lower social strata. Even Varga Mátyás ('Shoemaker' + Matthias) became a frequent variant from the 16th century on. "Name's day", i.e. celebrating someone's given or Christian name on the day of the patron saint, is much later attested as a common family event. Dugonics' explanation has been repeated in later collections of Hungarian proverbs. Indeed Dugonics, who also wrote fictional works about the age of King Matthias, had a penchant for transforming proverbs with which he was familiar, contriving explanations for them if nothing else. In other words, even in the case of some twenty sayings concerning King Matthias that figure in his writings, we cannot prove when they came into being. In some cases he refers to Galeotto Marzio's work. (Incidentally Hungarian sayings more frequently make mention of Jégtörö Mátyás ('Icebreaker Matthias') on February 24th, and the weather forecasts in connection with this than they do of the king himself.)

We have already mentioned that we know of many popular texts collected from the 19th century onwards. These and the official Hungarian Matthias tradition, however, must form the topic of another paper.

In 2008 a very fine exhibition was organized at the Ethnographic Museum in Budapest entitled "Legendary beings, enchanting flowers. The Renaissance We All Know and Love" (Fejös, 2008). The aim of the exhibition was to "rethink the 
relationship between the Renaissance and Hungarian folk artefacts of the 18th and 19th centuries." The several showcases and rooms were filled with printed books and woodcuts, stove tiles, guild-woven cloth, illuminated documents and manuscripts, figural images on painted wooden church ceilings, decorative vessels, furniture craft, embroidery on linen and hemp - as the chapters of the imposing catalogue tells. In all cases the historical continuity and the social affiliation of the exposed items was very complicated and the labels (e.g., "folk") are not without hesitation. In description and bibliography the international context was present, and many of the artifacts stemmed from Hungary, but not necessarily being "Hungarian" ones. All this is demonstrating again the difficulty of comparative and historical interpretation of the Renaissance in Hungary and its possible "folklore continuation".

Of course we greet the splendid exhibition with its 500 items carefully presented and described. Only after such collection of data can we start with the thorough analysis of the "Renaissance impact" on Hungarian folk culture.

It is not necessary to stress again that in all domains of the exhibition the motifs are of a wide international character, and they reach far beyond the borders of the then kingdom of Hungary. Not only the Renaissance is a "Europe-wide" phenomenon, but also the artifacts and motifs resembling the Renaissance in the folk cultures in Europe are of the very same character.

\section{Works cited}

Brill, Tony (2006) Tipologia legendei populare românești. 2. Legenda mitologică, legenda religioasă, legenda istorică (Type index of Romanian folk legends. 2. Mythological, religious and historical legends). Ediție îgrijită și prefață de I. Oprișan (București: Saeculum).

Burke, Peter (1978) Popular Culture in Early Modern Europe (London: Maurice Temple Smith).

Burkhart, Dagmar (1968) Untersuchungen zur Stratigraphie und Chronologie der südslavischen Volksepik (München: Otto Sagner).

Dávid, András (1978) Délszláv epikus énekek, magyar történeti hösök (South Slav Epic Songs and Hungarian historical heroes) (Újvidék: Forum Könyvkiadó).

Dugonics, András (1820, 2009) Magyar példa beszédek és jeles mondások, öszveszedte, és meg világositotta - - királyi oktató (Szeged: Grünn Orbán. Reprint: Szeged: Bába Kiadó).

Ernyey, József (1921) ‘Mátyás király a cseh néphagyományban’ (King Matthias in Czech folk traditions), Ethnographia Vol. 32, 92-100.

Faragó, József (1997) 'Két román népballada Mátyás királyról' (Two Romanian folk ballads on King Matthias), Helikon Vol. 8, No. 4 (234), 17-18.

Faragó, József (2005) Ismét a balladák földjén. Válogatott tanulmányok, cikkek (Returning to the Land of Ballads. Selected Studies) (Kolozsvár: Kriterion).

Fejös, Zoltán (ed.) (2008) Legendás lények, varázslatos virágok - a közkedvelt reneszánsz (Legendary beings, enchanting flowers - the Renaissance We All Know and Love) (Budapest: Néprajzi Múzeum) [With English Summary]. 
Funk \& Wagnalls (1950) Funk \& Wagnalls Standard Dictionary of Folklore Mythology and Legend. Maria Leach (ed.) (New York).

Galeottus, Martius Narniensis (1934) De egregie, sapienter, iocose dictis ac factis Regis Matthiae. Ladislaus Juhász (ed.) (Lipsiae: Teubner).

Grafenauer, Ivan (1951a) Slovenske pripovedke o kralju Matjažu (Slovenian narratives on King Matthias) (Ljubljana: Slovenska Akademija Znanosti in Umetnosti).

Grafenauer, Ivan (1951b) 'Slovenske ljudske pesmi o kralju Matjažu' (Slovenian folk songs on King Matthias), Slovenski Etnograf, 3-4, 184-240.

Habovštiak, Anton (1970) Proroctvo král'a Mateja. Povesti z Oravy (King Matthias foretelling the future. Stories from the Orava region) (Banská Bystrica, Stredoslovenské vydavatel'stvo).

Horváth, Iván et al. (ed.) (n.d.) Proceedings of the International Conference, May 20-25, 2008. Budapest "Matthias Rex 1458-1490. Hungary at the Dawn of the Renaissance (Budapest).

Jung, Károly (2008) Tanulmányok a Mátyás-tradició délszláv kapcsolatairól. Déli szláv Mátyásénekek és Mátyás-mondák eredetiben és magyar forditásban (Studies on Southern Slav contacts of King Matthias traditions. Southern Slav songs and legends in original, with Hungarian translations) (Újvidék, Forum).

Kardos, Tibor (1955) 'A “trufa”. Egy régi magyar irodalmi müfaj jellege és európai összefüggései' (The "jest". Characterization and European context of a medieval Hungarian literary genre), Filológiai Közlöny, 1, 111-38.

Kerča, Igor (2001) Matjaš, korol' Rusinuv (Matthias, king of the Ruthenians) (Užgorod: PoliPrint).

Komorovský, Ján (1957) Král' Matej Korvín v l'udovej prozaickej slovesnosti (King Matthias Corvin in folk narratives) (Bratislava: Slovenská Akadémia Vied).

Kríza, Ildikó (2007) A Mátyás-hagyomány évszázadai (Centuries of Matthias-Traditions) (Budapest: Akadémiai Kiadó).

Krstić, Branislav (1984) Indeks motiva narodnih pesama balkanskih slovena (Motif catalogue of folk songs of the Slavs in Balkan) (Beograd: Srpska Akademija Nauka i Umetnosti).

Kubinyi, András (2008) Matthias rex (Budapest: Balassi Kiadó).

Kuzelja, Zenon (1906) Ugors 'kij korol' Matvij Korvin v slavyans 'kij ustnij slovesnosti (The Hungarian King Matthias in Slavic oral tradition) (L’vov: Naukovo Tovaristvo im. Ševčenka).

Lukács, István (2001) A megváltó Mátyás király színeváltozásai a szlovén néphagyományban és szépirodalomban (The fortune of King Matthias, the Saviour, in Slovenian folk tradition and literature) (Budapest: Lucidus Kiadó).

Milošević-Djordjević, Nada (1971) Zajednička tematsko-sižejna osnova srpskohrvatskih neistorijskih epskih pesama i prozne tradijice (Themes and plots of a synthetical background of Serbo-Croatian non-historical epic songs and prose narratives) (Beograd: Filološki Fakultet Beogradskog Universiteta).

Ortutay, Gyula (1942) 'König Matthias in der mündlichen Überlieferung der Donauvölker', Ungarn, Vol. 3, April, 221-30.

Pável, Ágoston (1909) ‘Az Orpheus-monda rokonai a délszláv népköltészetben’ (Variants of Orpheus legends in South Slav folk poetry), Ethnographia, Vol. 20, 321-40.

Perfeckij, Eugen (1926) Podkarpatské a haličoruské tradice o králi Mátyášovi Corvinovi (Subcarpathian and Galician-Russian traditions on King Matthias Corvin) (Bratislava: Universita Komenského).

Raffai, Judit (2008) Vajdasági történetek Mátyás királyról (King Matthias narratives in the Vojvodina) (Újvidék - Szabadka, Forum).

Ranke, Kurt (1975- ) Enzyklopädie des Märchens (Berlin and New York: Walter de Gruyter).

Schott, Arthur and Schott, Albert (1971) Rumänische Volkserzählungen aus dem Banat. Märchen, Schwänke, Sagen. Neuausgabe besorgt von Rolf Wilh. Brednich und Ion Taloș (București: Kriterion Verlag). 
Solymossy, Sándor (1935) 'Monda' (Legend), in A magyarság néprajza (Ethnography of the Hungarians) (Budapest: Királyi Magyar Egyetemi Nyomda), 183-254.

Szegedy, Rezső (1916) ‘Mátyás királlyá választása a délszláv népköltészetben’ (Election of King Matthias in Southern Slav folk poetry), Ethnographia, Vol. 27, 47-60.

Szémán, István (1912) Korvin Mátyás magyar király a szláv népköltészetben (néphagyományban) (Hungarian King Matthias in Slav folk poetry /folklore/), in Századok, 46, 138-44.

Szörényi, László (1993) Hunok és jezsuiták. Fejezetek a magyarországi latin hösepika történetéböl (Huns and Jesuits. Chapters from the Latin language heroic epic in Hungary) (Budapest: AmfipressZ).

Szövérffy, Joseph (1968) 'History and Folk Tradition in Eastern Europe: Matthias Corvinus in the Mirror of Hungarian and Slavic Folklore', Journal of the Folklore Institute, Vol. 5, No. 1, $68-77$.

Ujváry, Zoltán (1990) Mátyás király Gömörben. Mondák, anekdoták a néphagyományban (King Matthias in County Gömör. Folk legends and anecdotes) (Debrecen: Kossuth Lajos Tudományegyetem, Néprajz Tanszék).

Voigt, Vilmos (2000) 'Karneválunk kérdései’ (Carnevalesc issues in Hungarian traditions), in Vilmos Voigt: Világnak kezdetétöl fogva. Történeti folklorisztikai tanulmányok (From all the beginning on. Studies in historical folklore) (Budapest: Universitas Kiadó), 287-306.

Zolnai, Béla (1921) 'Mátyás-mondáink eredete és fejlődése' (Origin and development of Hungarian legends about King Matthias), Irodalomtörténet, Vol. 10, 126-37. 